\title{
Thermal, Mechanical and Microstructural Analysis of Metakaolin Based Geopolymers
}

\author{
Liuski Roger Caballero ${ }^{\star}{ }^{\mathbb{D}}$, Maria das Dores Macedo Paiva ${ }^{a}$ Eduardo de Moraes Rego Fairbairn ${ }^{a}$, \\ Romildo Dias Toledo Filho ${ }^{a}$ \\ anstituto Alberto Luiz Coimbra de Pós-Graduação e Pesquisa de Engenharia- COPPE, Departamento \\ de Engenharia Civil, Universidade Federal do Rio de Janeiro - UFRJ, Av. Horácio Macedo 2030, \\ 21941-594, Ilha do Fundão, Rio de Janeiro, RJ, Brasil
}

Received: November 07, 2018; Revised: January 20, 2019; Accepted: February 03, 2019

\begin{abstract}
In the present work, geopolymer matrices were developed by alkali activation of metakaolin, using $\mathrm{NaOH}$ and sodium silicate as activators. The samples of metakaolin and matrices were studied by thermal analysis (TGA/DTA) at temperatures between $22^{\circ} \mathrm{C}$ and $1000^{\circ} \mathrm{C}$ in a nitrogen atmosphere with a heating rate of $10^{\circ} \mathrm{C} / \mathrm{min}$. The analyses showed gradual mass losses for MK1 and MK2, occurring in the temperature range of $350-700^{\circ} \mathrm{C}$, associated with the dehydroxylation of the kaolinite present in the metakaolin samples, when transforming into reactive metakaolin. Thermal analysis allowed to identify mass losses associated with the different events that occurred during the formation of the geopolymer structure. The formation of amorphous geopolymer networks was confirmed by the XRD and FTIR techniques. The quantitative analysis of XRD results by using the Rietveld method allowed determine the amorphous and crystalline content of the precursors and geopolymers. The results obtained, after analyzing the matrices, showed that the geopolymers obtained presented a mechanical performance comparable to systems found in the literature, with uniaxial compressive strengths ranging from 38-50 $\mathrm{MPa}$ and stiffness around $7 \mathrm{GPa}$. Hence, these systems are suitable for their future use as alternative binder materials for the production of mortars and concretes.
\end{abstract}

Keywords: geopolymers, metakaolin, thermal analysis, microstructural analysis, mechanical performance.

\section{Introduction}

For each ton of Portland cement produced, approximately one ton of $\mathrm{CO}_{2}$ is emitted into the atmosphere. Based on this, the concrete industry faces a growing challenge today, to search for alternative materials substituting conventional concrete, such as industrial waste and some mineral additions, with the aim of reducing the consumption of Portland cement and consequently $\mathrm{CO}_{2}$ emissions and other greenhouse gases that are harmful to the environment ${ }^{1,2}$.

In the scope of the demand for these new sustainable materials that have mechanical performance, stability and durability similar or superior to those traditionally used, geopolymeric cements are considered ${ }^{3,4}$.

Geopolymers or inorgnic polymers are binders, defined as solid and stable materials, formed by the alkaline activation of precursors, $\mathrm{Si}$ and $\mathrm{Al}$ sources, which are generally (but not always) supplied as a solid powder ${ }^{5,6}$. These sources are usually natural minerals, industrial residues and other materials with pozzolanic characteristics ${ }^{7,8}$. Geopolymers have excellent physical and mechanical properties. Their durability, resistance to acid attack and high initial mechanical resistance make them superior to traditional binders 9,10

The metakaolin (MK), obtained by the controlled burning of kaolin, has been one of the precursors most used

*e-mail: liuskiroger@gmail.com to produce geopolymers, since with the transformation of kaolin into metakaolin the resulting material becomes a much more reactive pozzolan. Some authors have obtained interesting results producing geopolymers from metakaolin, with great potential to be applied as alternative materials to conventional concrete based Ordinary Portland Cement (OPC concrete) ${ }^{8,11-13}$.

This paper presents the results of a study carried out where the structure of two metakaolin samples and the geopolymer matrices obtained by their alkaline activation were evaluated by thermal, mechanical and microstructural analysis. The main objective was to produce geopolymer matrices with suitable properties for their future use as alternative binder material to conventional binders used in the production of mortars and concretes.

\section{Experimental Procedure}

\subsection{Materials and characterization}

Two batches of metakaolin (MK1 and MK2) supplied by Metacaulim do Brasil, marketed as Metacaulim HP ULTRA, were used for the synthesis of geopolymers, as a source of silica and alumina. The density of MK1 and MK2 were $2.65 \mathrm{~g} / \mathrm{cm}^{3}$ and $2.81 \mathrm{~g} / \mathrm{cm}^{3}$, respectively, determined by using the Micromeritics Helium Gas Pycnometer, model 
AccuPyc 1340. The chemical composition was determined by analyses performed on the Shimadzu EDX-720 Energy Dispersive X-Ray. The number of oxides composing the precursors and the concentration in which their oxides were found are shown in Table 1 . The precursors are mostly composed of $\mathrm{SiO}_{2}$ and $\mathrm{Al}_{2} \mathrm{O}_{3}$.

The granulometric distribution was obtained using the Malvern MasterSizer 2000 laser granulometer. As indicated by the mean diameters $\left(\mathrm{d}_{10}, \mathrm{~d}_{50}\right.$ and $\left.\mathrm{d}_{90}\right)$ in Table 2 , up to $10 \%$ of the particles of both MKs have a particle size smaller than around $3 \mu \mathrm{m}$. Above $10 \%$, the particles of the MK2 sample were smaller than those of MK1.

The mineralogical analysis of the raw materials and the geopolymers admixtures was performed by powder X-ray diffraction (XRD), using the Bruker-AXS D4 Endeavor diffractometer with $\mathrm{Co} \mathrm{K} \alpha$ radiation. The samples were step-scanned at $0.02^{\circ} 2 \theta$ and integrated at the step time of $1.83 \mathrm{~s} / \mathrm{step}$. As shown in Figure 1, quartz $\left(\mathrm{SiO}_{2}\right)$ is the major crystalline phase contaminant present in both MK1 and MK2. Other minor crystalline contaminants are kaolinite, microcline, muscovite, anatase and illite.

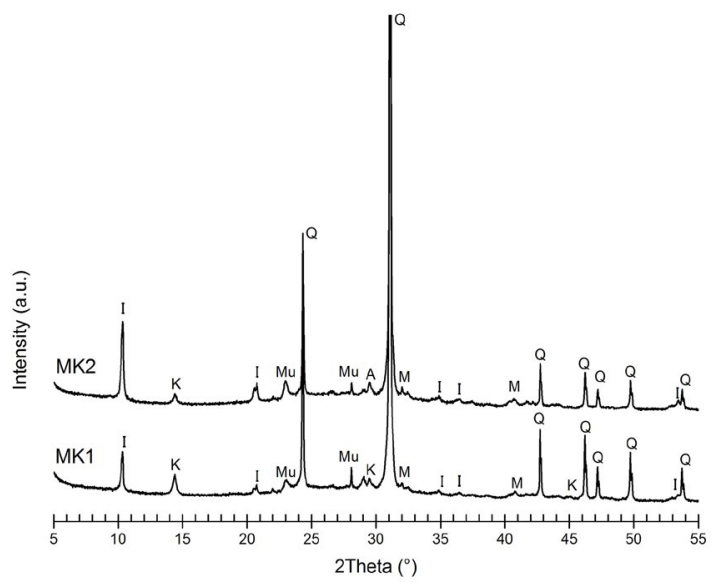

Figure 1. XRD spectra of MK1 and MK2. K: Kaolinite $\left(\mathrm{Al}_{2} \mathrm{Si}_{2} \mathrm{O}_{5}(\mathrm{OH})\right)$; $\mathrm{M}$ : Microcline $\left(\mathrm{KAlSi}_{3} \mathrm{O}_{8}\right)$; Mu: Muscovite $\left(\mathrm{KAl}_{2}\left(\mathrm{AlSi}_{3} \mathrm{O}_{10}\right)(\mathrm{F}, \mathrm{OH})_{2}\right.$; A:Anatase $\left(\mathrm{TiO}_{2}\right)$; Q: Quartz $\left(\mathrm{SiO}_{2}\right)$; I: Illite $\left(\left(\mathrm{K}, \mathrm{H}_{3} \mathrm{O}\right)(\mathrm{Al}, \mathrm{Mg}, \mathrm{Fe})_{2}\right.$ $\left.(\mathrm{Si}, \mathrm{Al})_{4} \mathrm{O}_{10}\left[(\mathrm{OH})_{2},\left(\mathrm{H}_{2} \mathrm{O}\right)\right]\right)$.

A quantitative analysis of XRD results allowed the determination of the amorphous content of the precursors and geopolymers using the total multiphase spectrum refinement method (Rietveld method) with Bruker-AXS TOPAS software. Fluorite $\left(\mathrm{CaF}_{2}\right.$, PDS-00-035-0846) was used as an internal standard. The crystal structure information of the refined phases
Table 2. Granulometric distribution of metakaolins.

\begin{tabular}{lccc}
\hline \multirow{2}{*}{ Material } & \multicolumn{3}{c}{ Diametre $(\boldsymbol{\mu m})$} \\
\cline { 2 - 4 } & $\mathbf{d}_{\mathbf{1 0}}$ & $\mathbf{d}_{\mathbf{5 0}}$ & $\mathbf{d}_{\mathbf{9 0}}$ \\
\hline MK1 & 3.36 & 24.93 & 61.24 \\
MK2 & 3.09 & 17.95 & 53.42 \\
\hline
\end{tabular}

Table 3. Crystalline-amorphous quantification of MK1 and MK2 (T\%).

\begin{tabular}{lcc}
\hline Percent & MK1 & MK2 \\
\hline Crystalline & 24.5 & 52.6 \\
Amorphous & 75.5 & 47.4 \\
Total & 100.0 & 100.0 \\
Crystalline phase & & \\
kaolinite & 8.7 & 4.4 \\
muscovite & 2.4 & 3.4 \\
quartz & 2.9 & 29.7 \\
anatase & 1.7 & 0.6 \\
microcline & 1.2 & 3.3 \\
illite & 7.6 & 11.2 \\
\hline
\end{tabular}

derives from the crystal structure Bruker-AXS database, was obtained from the Crystallography Open Database (COD) and International Crystal Structure Database (ICSD). Table 3 shows the percentage by mass (T\%) of the amorphous and crystalline contents of each precursor used, as well as the crystalline phases obtained after the refinement. The MK1 precursor was more amorphous (75.4\%) than MK2 (47.4\%), which can be attributed to variations in the composition of the kaolin batches used and/or the variation in the calcination process, used by the supplier to produce metakaolin. Table 3 shows that kaolinite is the predominant crystalline phase in MK1, whereas in MK2 it is quartz, but both phases are present in MK1 and MK2, as well as muscovite, anatase, microcline and illite, which were found in smaller quantities.

Fourier transform infrared (FTIR) spectra of MK1, MK2 and geopolymers were collected in a VARIAN 3100 spectrometer Model-Excalibur in absorbance mode. Sample pellets were prepared using the normal $\mathrm{KBr}$ procedure, dried in an oven at $60^{\circ} \mathrm{C}$ overnight and pressed before spectra were taken. The analyses were performed in the spectral range of 4000 to $400 \mathrm{~cm}^{-1}$, with a resolution of $4 \mathrm{~cm}^{-1}$ and the number of scans was 60. FTIR spectra (Figure 2) present the main usual bands, described as follows: below $900 \mathrm{~cm}^{-1}$, related to the asymmetric vibration of the $\mathrm{Si}-\mathrm{O}-(\mathrm{Si}, \mathrm{Al})$ bonds, around $1000 \mathrm{~cm}^{-1}$, related to $\mathrm{Si}-\mathrm{O}-\mathrm{Si}$ bonds and the characteristic bands of kaolinite at about 3400 and $1600 \mathrm{~cm}^{-1} 14,15$, due to

Table 1. Chemical composition, normalized to $100 \%$ by mass.

\begin{tabular}{lcccccccccc}
\hline \multirow{2}{*}{ Material } & \multicolumn{10}{c}{ Oxides (wt.\%) } \\
\cline { 2 - 11 } & $\mathbf{A l}_{2} \mathbf{O}_{3}$ & $\mathbf{S i O}_{2}$ & $\mathbf{F e}_{2} \mathbf{O}_{3}$ & $\mathbf{T i O}_{2}$ & $\mathbf{S O}_{3}$ & $\mathbf{K}_{2} \mathbf{O}$ & $\mathbf{Z r O}_{2}$ & $\mathbf{B a O}_{2}$ & $\mathbf{C r}_{2} \mathbf{O}_{3}$ & $\mathbf{O t h e r s}$ \\
\hline MK1 & 48.74 & 45.01 & 2.74 & 1.52 & 0.99 & 0.63 & 0.01 & 0.27 & 0.02 & 0.06 \\
MK2 & 41.69 & 51.85 & 1.91 & 1.38 & 1.09 & 1.89 & 0.03 & - & 0.01 & 0.14 \\
\hline
\end{tabular}

(-): oxide not found. 


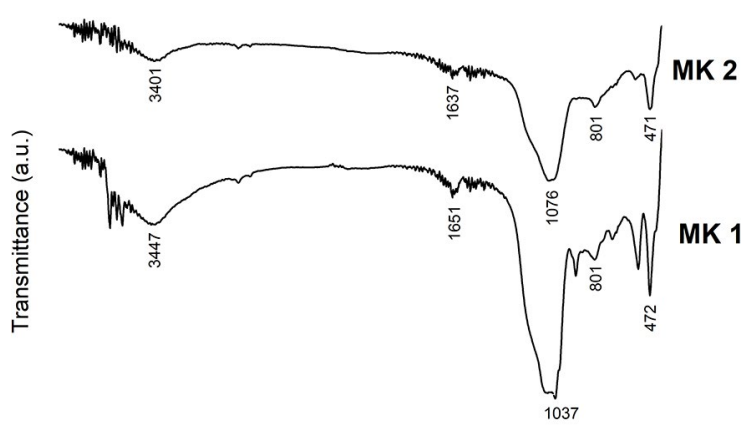

$$
\begin{aligned}
& \begin{array}{llllllllll}
4000 & 3600 & 3200 & 2800 & 2400 & 2000 & 1600 & 1200 & 800 & 400
\end{array} \\
& \text { Wavenumber }\left(\mathrm{cm}^{-1}\right)
\end{aligned}
$$

Figure 2. FTIR spectra of raw metakaolins.

$\mathrm{O}-\mathrm{H}$ stretching and bending modes of absorbed molecular water in the metakaolin structure ${ }^{11,13,15}$. The band in the wavenumber range $3500-3300 \mathrm{~cm}^{-1}$ is weaker for MK2 than that for MK1 and the signals located in the range $3700-3600 \mathrm{~cm}^{-1}$ are almost imperceptible, which confirms the lower kaolinite content of MK2 when compared to that of MK1 ${ }^{15}$.

Thermal analyses (TGA-DTA) were performed on the TA Instruments SDT-Q600 Simultaneous TGA/DTA/DSC equipment. A nitrogen atmosphere was used with a flow rate of $100 \mathrm{~mL} / \mathrm{min}$ and heating rate of $10^{\circ} \mathrm{C} / \mathrm{min}$. Prior to performing the tests, the powder samples were treated by placing them in a glass beaker at $60^{\circ} \mathrm{C}$ during 24 hours in order to eliminate the surface moisture of the material. The tests were carried out starting from room temperature $\left(22^{\circ} \mathrm{C}\right)$ up to $1000^{\circ} \mathrm{C}$ using a platinum pan to avoid the occurrence of reactions between the material and the pan (an aluminum pan could react with the precursors and the geopolymers due to the presence of $\mathrm{Al}_{2} \mathrm{O}_{3}$ in the latter's chemical composition). In order to process the results of the tests, the Universal Analysis 2000 program of TA Instruments was used.

Figure 3 shows the thermogravimetric analysis for MK1 and MK2 (TGA) and Table 4 the correspondent mass losses and its intervals. Gradual mass losses in the order of 4 and $1 \%$ for MK1 and MK2, respectively, occurring in the temperature range $350-580^{\circ} \mathrm{C}$, are associated with the dehydroxylation of the kaolinite present in the metakaolins, transforming into reactive metakaolin ${ }^{11,15}$. MK2 shows a minor mass loss due to the lesser amount of kaolinite in its composition.

The differential thermal analysis (DTA) curves shown in Figure 4 illustrate that the typical endothermic peaks of kaolinite associated with the mass losses, shown in Figure 3 between $400-500^{\circ} \mathrm{C}$, were not identified. The absence of these peaks is due to the low content (less than $10 \%$ ) of kaolinite found in both MKs ${ }^{15}$. On the other hand, an exothermic peak near $1000^{\circ} \mathrm{C}$ was identified in $\mathrm{MK} 1$ and $\mathrm{MK} 2$, which according to ${ }^{15}$ corresponds to the transformation of the metakaolin phase in the spinel phase, which will allow finally nucleation of the mullite and explain the weight loss observed in TG plots for both metakaolin samples.
The main alkaline activator used was $\mathrm{NaOH}$, which was supplied by the company VETEC-SIGMA ALDRICH, in the form of P.A. lentils, with $97 \%$ purity.

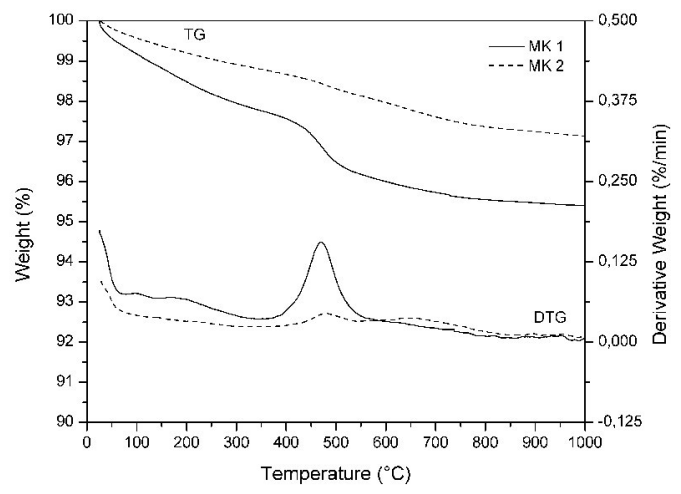

Figure 3. TGA curves of MK1 and MK2.

Table 4. Mass loss intervals for raw materials (MK1 and MK2).

\begin{tabular}{llcc}
\hline $\begin{array}{l}\text { Raw } \\
\text { Material }\end{array}$ & \multicolumn{1}{c}{ Event } & $\begin{array}{c}\text { Temperature } \\
\text { Interval }\left({ }^{\circ} \mathbf{C}\right)\end{array}$ & $\begin{array}{c}\text { Loss Weight } \\
(\mathbf{\%})\end{array}$ \\
\hline & Water loss & $22-350$ & 2.2 \\
& $\begin{array}{l}\text { Kaolin } \\
\text { Dehydroxilation } \\
\text { Kaolin to } \\
\text { metakaolin } \\
\text { transformation }\end{array}$ & $350-580$ & 1.7 \\
& $\begin{array}{l}\text { Metakaolin } \\
\text { to spinel } \\
\text { transformation }\end{array}$ & Above 580 & \\
& Water loss & 22-380 & \\
& $\begin{array}{l}\text { Kaolin } \\
\text { Dehydroxilation } \\
\text { Kaolin to } \\
\text { metakaolin } \\
\text { transformation }\end{array}$ & & \\
MK2 & $380-580$ & 0.7 \\
& $\begin{array}{l}\text { Metakaolin } \\
\text { to spinel } \\
\text { transformation }\end{array}$ & Above 580 & \\
\hline
\end{tabular}

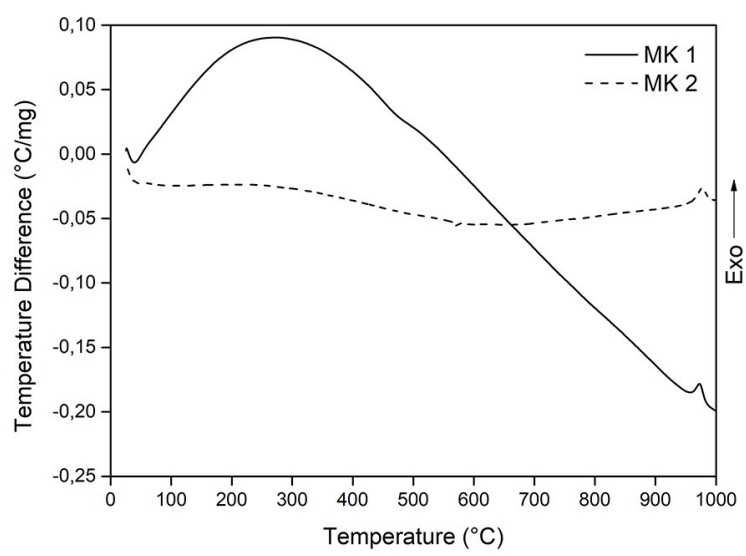

Figure 4. DTA curves of MK1 and MK2. 
Alkali Sodium Silicate R2252 was used as alkaline activator and additional silica source, with a density of $1.58 \mathrm{~g} / \mathrm{L}$ at $25^{\circ} \mathrm{C}$, and the following chemical composition: $14.95 \%$ of $\mathrm{Na}_{2} \mathrm{O}, 33.20 \%$ of $\mathrm{SiO}_{2}$ and $51.85 \%$ of $\mathrm{H}_{2} \mathrm{O}$. Diatom Mineração Ltda., a reference in Latin America for producing this material, supplied the sodium silicate used.

\subsection{Synthesis of geopolymers}

Two geopolymer pastes were developed by alkaline activation of MK1 and MK2. After conducting a series of experimental tests, the matrices presenting the better physical and mechanical behavior were identified. Two mix designs were selected as pure geopolymers (G1 and G2). G1 was designed using MK1 with the following molar ratios: $\mathrm{SiO}_{2} /$ $\mathrm{Al}_{2} \mathrm{O}_{3}: 2.45, \mathrm{Na}_{2} \mathrm{O} / \mathrm{Al}_{2} \mathrm{O}_{3}: 0.58$ and $\mathrm{H}_{2} \mathrm{O} / \mathrm{Na}_{2} \mathrm{O}: 16.50$. For synthesizing $\mathrm{G} 2$, MK2 was used with the following molar ratios: $\mathrm{SiO}_{2} / \mathrm{Al}_{2} \mathrm{O}_{3}: 3.0, \mathrm{Na}_{2} \mathrm{O} / \mathrm{Al}_{2} \mathrm{O}_{3}: 0.82$ and $\mathrm{H}_{2} \mathrm{O} / \mathrm{Na}_{2} \mathrm{O}$ : 12 , as summarized on Table 5 . The activating solution was composed of sodium silicate, sodium hydroxide solution prepared to a concentration of $10 \mathrm{M}$, and deionized water.

The geopolymers compositions are summarized in Table 5 and their compositions in mass by unit volume $\left(\mathrm{kg} / \mathrm{m}^{3}\right)$ are shown in Table 6.

The synthesis of geopolymers was carried out by first dissolving sodium hydroxide pellets in deionized water, obtaining a solution with concentration of 10M. Sodium silicate solution was then added to the previous solution and the final activation solution was allowed to cool down to room temperature $\left(\sim 22^{\circ} \mathrm{C}\right)$.

The geopolymers binders were mixed according to the API RP 10B-2-2015 ${ }^{17}$ and ABNT NBR 9831-2008 ${ }^{18}$ standards, in a waring blender $24 \mathrm{CB} 10 \mathrm{C}$. Minor adjustments in mixing procedure was conducted to keep the same mixing energy required by ${ }^{17,18}$, in order to prepare $750 \mathrm{~mL}$ paste volume. The activation solution was poured into the mixer vessel, the metakaolin was added gradually within $19 \mathrm{~s}$ at $4000 \mathrm{rpm}$. The speed was increased to $12000 \mathrm{rpm}$ and

Table 5. Molar ratios adopted for designing the geopolymer matrices.

\begin{tabular}{lcccc}
\hline Mixture & $\begin{array}{c}\mathbf{S i O}_{2} / \\
\mathbf{A l}_{2} \mathbf{O}_{\mathbf{3}} \text { (wt.\%) }\end{array}$ & $\begin{array}{c}\mathbf{N a}_{2} \mathbf{O} / \\
\mathbf{A l}_{2} \mathbf{O}_{\mathbf{3}} \text { (wt.\%) }\end{array}$ & $\begin{array}{c}\mathbf{H}_{2} \mathbf{O} / \\
\mathbf{N a}_{2} \mathbf{O} \\
(\mathbf{w t . \%} \%\end{array}$ & $\begin{array}{c}\text { liquid/ } \\
\text { solid } \\
\text { (wt.) }\end{array}$ \\
\hline $\mathrm{G} 1$ & 2.45 & 0.58 & 16.50 & 1.25 \\
$\mathrm{G} 2$ & 3.00 & 0.82 & 12.00 & 1.14 \\
\hline
\end{tabular}

Table 6. Geopolymers compositions in $\mathrm{kg} / \mathrm{m}^{3}$.

\begin{tabular}{lcc}
\hline Material & G1 & G2 \\
\hline MK1 & 777 & - \\
MK2 & - & 871 \\
Sodium silicate & 588 & 570 \\
NaOH (10M) & 189 & 390 \\
Water & 193 & 36 \\
\hline
\end{tabular}

kept for $44 \mathrm{~s}$ to obtain a homogeneous paste, totalizing the mixing time as $63 \mathrm{~s}$.

After concluding the mixing process, three cylindrical specimens of each G1 and G2 geopolymers, with $50 \mathrm{~mm}$ (diameter) x $100 \mathrm{~mm}$ (height), were cast in two layers, vibrating each layer for 60 seconds to remove entrained air. Afterwards, the samples were cured in water bath at $22 \pm 2{ }^{\circ} \mathrm{C}$, for 7 days, prior to testing under uniaxial compressive loads. Fragments of cured geopolymer samples were extracted after the tests to be used for the thermal and microstructural analyses by XRD and FTIR. The unconfined compressive strengths of geopolymer paste samples were determined following ABNT NBR 5739-2007 ${ }^{19}$ using a 200kN Wykeham Farrance press. The loading velocity was $0.1 \mathrm{~mm} \mathrm{~min}^{-1}$. The axial strain was calculated from stroke measurements during the tests with two LVDTs. The stiffness (Young's modulus, E) was calculated from the stress-strain curves, using the secant modulus from two points in the linear elastic section, the first corresponding to $40 \%$ of the failure stress, and the second corresponding to a strain of $50 \mu \mathrm{S}$ (Equation 1). Each reported value corresponds to the average of 3 measurements, for compressive tests.

$$
E=\frac{\sigma_{c 2}-\sigma_{c 1}}{\varepsilon_{c 2}-\varepsilon_{c 1}}
$$

The fragments were milled until obtaining a particle size smaller than $106 \mu \mathrm{m}$. Immediately, the geopolymerization reaction was stopped using a solution of alcohol/acetone (1:1 vol.\%/vol.\%), as recommended by different investigators ${ }^{20,21}$.

\section{Results and Discussion}

\subsection{XRD analysis}

XRD analysis of geopolymers showed that, just as in MK1, kaolinite is the predominant crystalline phase in G1 and that quartz is the predominant phase in $\mathrm{G} 2$, as it is in MK2. Table 7 shows the percentage by mass (T\%) obtained

Table 7. Crystalline-amorphous quantification of G1 and G2 (T\%).

\begin{tabular}{lcc}
\hline Percent & G1 & G2 \\
\hline Crystalline & 8.1 & 25.8 \\
Amophous & 91.9 & 74.2 \\
Total & 100.0 & 100.0 \\
Crystalline phase & & \\
kaolinite & 6.2 & 2.9 \\
muscovite & 0.0 & 1.2 \\
quartz & 0.7 & 13.2 \\
anatase & 0.7 & 0.4 \\
microcline & 0.5 & 0.8 \\
illite & - & 7.3
\end{tabular}

(-): phase not found. 
by the quantification of amorphous-crystalline material present in the studied geopolymers.

XRD diffratograms (Figure 5) show a typical broad amorphous hump around $25-40^{\circ} 2 \theta$, less pronounced in G2, due to its higher crystalline content, compared to G1. This suggests a higher degree of geopolymerization and that a purer geopolymer binder was obtained for G1, with $90 \%$ of amorphous content found by RQACA. This may explain the higher compressive strength of G1, compared to G2. This typical broad hump is the characteristic signature of amorphous geopolymers. Quartz $\left(\mathrm{SiO}_{2}\right)$ is the major crystalline phase contaminant present in geopolymer binders. Other minor crystalline contaminants are kaolinite, microcline, illite, muscovite and anatase, which originate from the metakaolin. precursors.

Most of these and other phases found in precursor materials were still present in the geopolymers as non-reactive contaminants, but it was noted that the content of crystalline phases found in geopolymers was lower than in metakaolins, suggesting that these phases are partially reactive.

The Rietveld method showed that G1 had a 92\% amorphous content, while G2 had a lower amorphous content of $74 \%$,

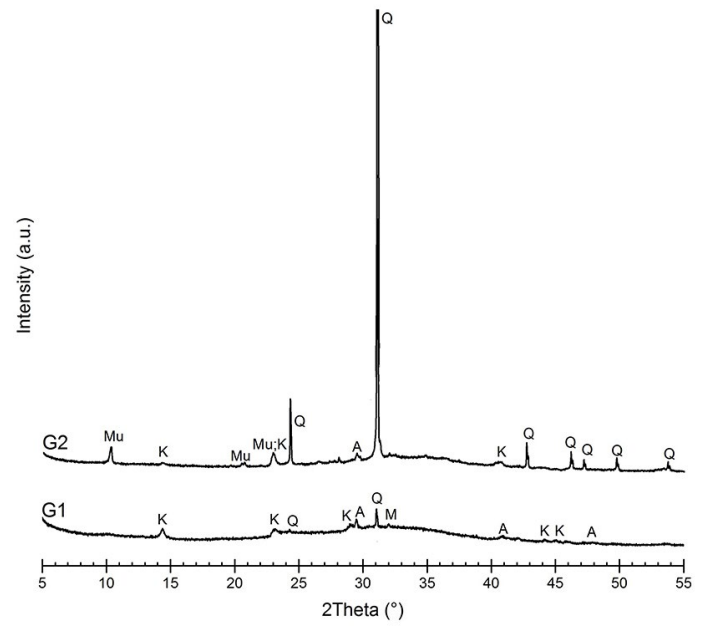

Figure 5. XRD spectra of $\mathrm{G} 1$ and $\mathrm{G} 2$. $\mathrm{K}$ : Kaolinite $\left(\mathrm{Al}_{2} \mathrm{Si}_{2} \mathrm{O}_{5}(\mathrm{OH})\right)$; M: Microcline $\left(\mathrm{KAlSi}_{3} \mathrm{O}_{8}\right) ; \mathrm{Mu}$ : Muscovite $\left(\mathrm{KAl}_{2}\left(\mathrm{AlSi}_{3} \mathrm{O}_{10}\right)(\mathrm{F}, \mathrm{OH})_{2}\right.$; A:Anatase $\left(\mathrm{TiO}_{2}\right)$; Q: Quartz $\left(\mathrm{SiO}_{2}\right)$.

which is directly related to the higher amorphous content of MK1 when compared to MK2, as shown in Table 6.

\subsection{FTIR analysis}

FTIR analysis, shown in Figure 6, illustrates that the bands found in the analyses of MK1 between $3600-3700 \mathrm{~cm}^{-1}$, characteristics of kaolinite, are absent for the G1 sample. This result is associated with the lower presence of the kaolinite phase in G1 when compared to MK1, which corresponds to the Rietveld results, confirming the hypothesis that a part of the crystalline phases present in the precursors could be partially reactive. Typical bands of kaolinite with a peak around $3400 \mathrm{~cm}^{-1}$ were still present in the geopolymers. As well as in the metakaolins analyses, this peak at $3434 \mathrm{~cm}^{-1}$ for G1 was more intense than for G2 due to the higher amount of kaolinite found by the Rietveld refinement in G1.

Figure 6 presents other characteristic bands of geopolymers, described as follows: below $700 \mathrm{~cm}^{-1}$, related to the asymmetric vibration of the $\mathrm{Si}-\mathrm{O}-(\mathrm{Si}, \mathrm{Al})$ bonds, around $1000 \mathrm{~cm}^{-1}$, related to $\mathrm{Si}-\mathrm{O}-\mathrm{Si}$ bonds and around $1600 \mathrm{~cm}^{-1}$, attributed to stretching vibrations $(\mathrm{H}-\mathrm{O})$ of absorbed or structural water molecules present in the geopolymer porosity ${ }^{11-13}$.

While in the unreacted MK1 and MK2 the $\mathrm{Si}-\mathrm{O}-\mathrm{Si}$ band appears at $1037 \mathrm{~cm}^{-1}$ and $1076 \mathrm{~cm}^{-1}$, in the activated samples it shifts to lower wave numbers in both systems studied (between 1016 and $1010 \mathrm{~cm}^{-1}$ ). This shift occurs due to the formation of aluminosilicate gel, indicating the condensation of $\mathrm{Si}-\mathrm{O}$ as well as $\mathrm{SiO}_{4}$ and $\mathrm{AlO}_{4}$ tetrahedra in the geopolymer network ${ }^{22,23,24}$. Several weaker bands in the range from 600 to $800 \mathrm{~cm}^{-1}$ replace the characteristic metakaolin $\mathrm{Si}-\mathrm{O}-\mathrm{Al}$ band at $801 \mathrm{~cm}^{-1}$, after the geopolymerization ${ }^{24}$. The band at about 460 to $600 \mathrm{~cm}^{-1}$ is due to $\mathrm{Si}-\mathrm{O}$ bending vibration ${ }^{24}$. The smaller peak at $2926 \mathrm{~cm}^{-1}$ is related to $\mathrm{C}-\mathrm{O}$ bonds. The lower peak intensities found for $\mathrm{G} 2$ are attributed to the higher MK2 crystalline content compared to G1, which agrees with the XRD analysis.

\subsection{Thermal analysis (TGA/DTA)}

The thermograms presented in Figure 7, corresponding to the thermal analyses of G1 and G2, showed the occurrence of three phenomena. The first is identified by the occurrence of pronounced mass loss (10-15\%) for both geopolymers, between 22 and $300^{\circ} \mathrm{C}$, associated to the two endothermic peaks visible in the DTA curves (Figure 8 ). The $15 \%$ mass loss observed for both geopolymers are due possible humidity reincorporation as the samples were not analyzed immediately after the treatment and properly stored before the analysis.

These peaks, according to several authors ${ }^{16,25,26}$, are associated with the loss of free or slightly bound water in the geopolymer structure. It can be appreciated that this peak has lower intensity for G2 than for G1, which indicates the presence of less free water in its structure.

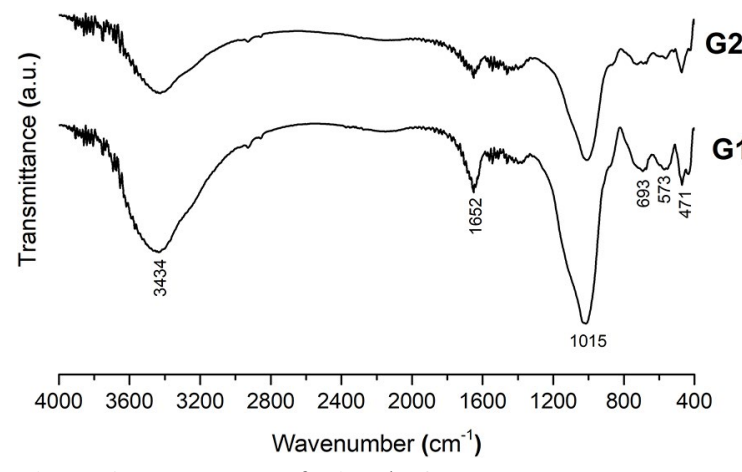

Figure 6. FTIR spectra of G1 and G2. 


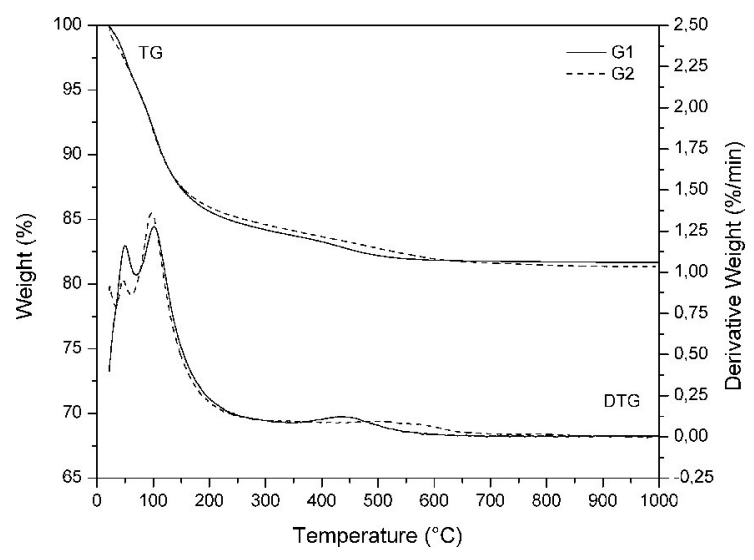

Figure 7. TGA curves of G1 and G2.

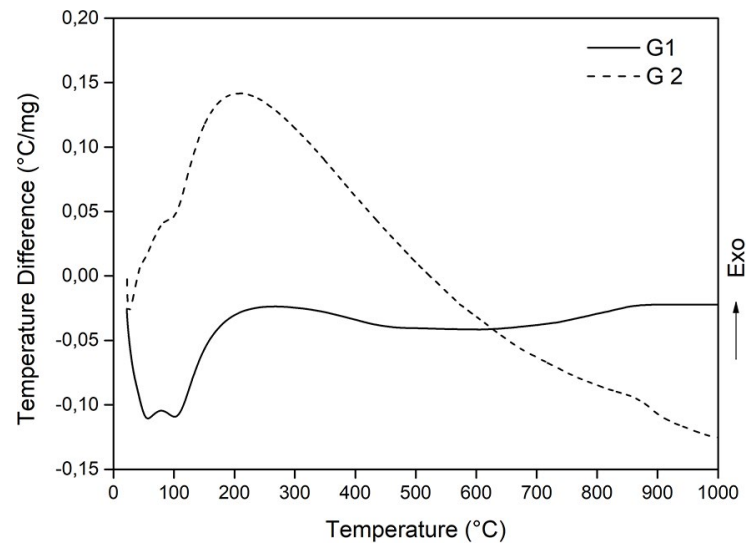

Figure 8. DTA curves of G1 and G2.

The second phenomenon is defined by the slight loss of mass (about $2 \%$ ) from 350 to $700^{\circ} \mathrm{C}$, associated with the dehydroxylation of the geopolymer matrix and of the kaolinite present in metakaolin, the removal of surface hydroxyl groups $(-\mathrm{OH})$ and the formation of new $\mathrm{Si}-\mathrm{O}-\mathrm{Si}$ bonds, with water release, that produce additional shrinkage in the geopolymer matrix. Above $600^{\circ} \mathrm{C}$, both samples showed very small mass losses (below $0.3 \%$ ), on TGA (Figure 7) plots, suggesting a further water release. ${ }^{11,14,15,27}$. The mass losses observed are summarized in Table 8.

As well as in the metakaolins, the typical endothermic peaks of kaolinite between temperatures of $350-700^{\circ} \mathrm{C}$ were not identified in the geopolymers (Figure 8), due to the reduced quantities of kaolinite in G1 and G2, being even lower than those found in MK1 and MK2, respectively.

\subsection{Mechanical testing}

Stress-strain curves for geopolymers 1 and 2 are displayed in Figure 9. All curves exhibit a well-defined elastic regime and no post-peak residual strength, confirming that the two geopolymers display an elastic-brittle behavior, with similar initial elastic moduli. Compressive strengths $\left(f_{c}\right)$, secant elastic moduli (E) and maximum strain $\left(\varepsilon_{\mathrm{m}}\right)$ of the geopolymers are summarized in Table 8 .

Geopolymer G1 shows higher compressive strength and failure strain compared to G2, as can be seen in Table 9 and Figure 9. The opposite could be expected, considering that $\mathrm{G} 2$ has a Si/Al ratio of 3, closer to the theoretical value of 4 than the $\mathrm{Si} / \mathrm{Al}$ ratio of $\mathrm{G} 2$ (2.45). This can be attributed to the higher amorphous content $(75 \%)$ of the MK1 precursor used in G1, compared to the amorphous content of MK2 $(45 \%)$, used in $\mathrm{G} 2$.

Table 8. Mass loss intervals for geopolymers (G1 and G2).

\begin{tabular}{|c|c|c|c|}
\hline $\begin{array}{l}\text { Raw } \\
\text { Material }\end{array}$ & Event & $\begin{array}{l}\text { Temperature } \\
\text { Interval }\left({ }^{\circ} \mathrm{C}\right)\end{array}$ & $\begin{array}{c}\text { Loss Weight } \\
(\%)\end{array}$ \\
\hline \multirow{3}{*}{ G1 } & Water loss & $22-350$ & 16.2 \\
\hline & $\begin{array}{l}\text { Kaolin } \\
\text { Dehydroxilation } \\
\text { Kaolin to } \\
\text { metakaolin } \\
\text { transformation }\end{array}$ & $350-600$ & 1.8 \\
\hline & $\begin{array}{l}\text { Geopolymer } \\
\text { matrix water } \\
\text { release }\end{array}$ & Above 600 & 0.3 \\
\hline \multirow{3}{*}{ G2 } & Water loss & $22-350$ & 15.9 \\
\hline & $\begin{array}{l}\text { Kaolin } \\
\text { Dehydroxilation } \\
\text { Kaolin to } \\
\text { metakaolin } \\
\text { transformation }\end{array}$ & $350-700$ & 2.5 \\
\hline & $\begin{array}{l}\text { Geopolymer } \\
\text { matrix water } \\
\text { release }\end{array}$ & Above 700 & 0.2 \\
\hline
\end{tabular}

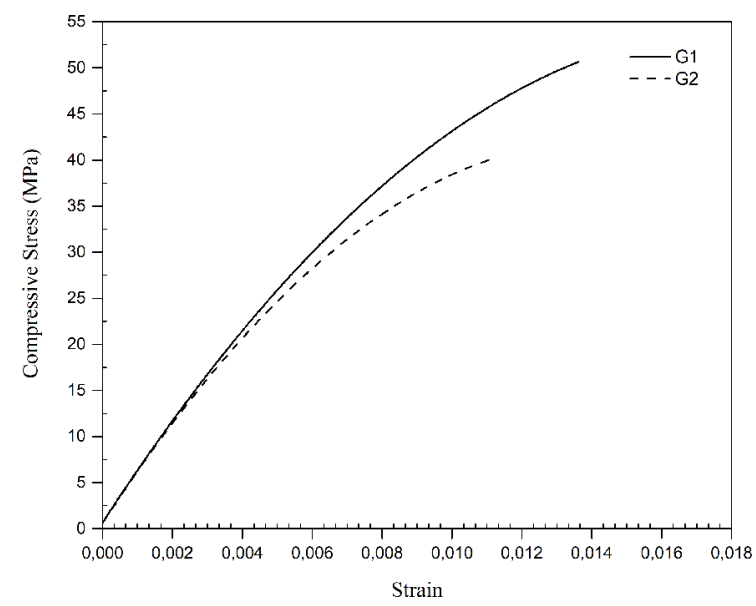

Figure 9. Stress-strain curves for the geopolymer binders

Table 9. Compression mechanical parameters for the geopolymer binders.

\begin{tabular}{lccc}
\hline Mixture & $\mathbf{f}_{\mathbf{c}}(\mathbf{M P a})$ & $\boldsymbol{\varepsilon}_{\mathbf{m}}$ & $\mathbf{E}(\mathbf{G P a})$ \\
\hline $\mathrm{G} 1$ & $50.22 \pm 0.99$ & $0.013 \pm 0.001$ & $6.32 \pm 0.02$ \\
$\mathrm{G} 2$ & $38.86 \pm 1.47$ & $0.010 \pm 0.001$ & $7.22 \pm 0.12$ \\
\hline
\end{tabular}




\section{Conclusions and Final Considerations}

In this study, two geopolymer systems were produced from the alkaline activation of two batches of metakaolin with different amorphous contents. The formation of amorphous geopolymer networks was confirmed by the XRD and FTIR techniques.

Refinement by the Rietveld method allowed to conclude that the amount of crystalline material in the precursors is determinant in the final product obtained, which was reflected by the fact that G1 was more amorphous (92\%) than $\mathrm{G} 2(74 \%)$, as it was for their respective precursors MK1 and MK2. The XRD results also demonstrate that the crystalline contaminants present in the precursor are found to be mostly unreacted in the final product, but the levels of the crystalline phases found in the geopolymers were lower than those in the precursors which indicates that some of these phases may be reactive.

The thermal analyses showed weight losses related to humidity loss, kaolin dehydroxylation and transformation to metakaolin, as well transformation of metakaolin to spinel, as mentioned by ${ }^{15}$.

The metakaolin-based geopolymer pastes G1 and G2 presented a mechanical performance comparable to systems found in the literature, with uniaxial compressive strengths ranging from 38 to $50 \mathrm{MPa}$ and stiffness around $7 \mathrm{GPa}$. The paste $\mathrm{G} 1$ produced with MK1, which has a greater amorphous content and higher reactivity, was significantly stronger than $\mathrm{G} 2$, which is based on the more crystalline precursor MK2. Overall, these systems are suitable for their future use as alternative binder materials to conventional binders used in the production of mortars and concretes, as long as quality control procedures are adopted to evaluate properly the amorphicity of different raw materials.

\section{Acknowledgment}

The authors thank their technical support staff of the Civil Engineering Program of COPPE-UFRJ, LABESTUFRJ, NUMATS, IMA-UFRJ and CETEM laboratories. The research leading to these results has received funding from CAPES and COPPETEC foundation.

\section{References}

1. McLellan BC, Williams RP, Lay J, van Riessen A, Corder GD. Costs and carbon emissions for geopolymer pastes in comparison to ordinary portland cement. Journal of Cleaner Production. 2011;19(9-10):1080-1090. DOI: 10.1016/j.jclepro.2011.02.010

2. Mota LMF, Melo KA, Andrade AF, Queiroz MdeM, Carneiro AMP. Análise das Propriedades do estado endurecido de concretos empregando metacaulim e aditivo superplastificante. In: $48^{\circ}$ Congresso Brasileiro do Concreto - IBRACON 2006; 2006 Sep 22-27; Rio de Janeiro, RJ, Brazil.
3. Davidovits J. Chemistry of Geopolymeric Systems, Terminology. In: Proceedings of 1999 Geopolymer International Conference; 1999 Jul 1-2; Saint Quentin, France.

4. Barbosa VFF, MacKenzie KJD. Thermal behaviour of inorganic geopolymers and composites derived from sodium polysialate. Materials Research Bulletin. 2003;38(2):319-331. DOI: 10.1016/ S0025-5408(02)01022-X

5. Duxson P, Provis JL, Lukey GC, Mallicoat SW, Kriven WM, van Deventer JSJ. Understanding the relationship between geopolymer composition, microstructure and mechanical properties. Colloids and Surfaces A: Physicochemical and Engineering Aspects. 2005;269(1-3):47-58. DOI: 10.1016/j. colsurfa.2005.06.060

6. Provis JL, van Deventer JSJ, eds. Geopolymers - Structures, Processing, Properties and Industrial Applications. Cambridge: Woodhead Publishing; 2009. DOI: 10.1533/9781845696382

7. Bernal SA, Bejarano J, Garzón C, Mejía de Gutiérrez R, Delvasto $\mathrm{S}$, Rodríguez ED. Performance of refractory aluminosilicate particle/fiber-reinforced geopolymer composites. Composites Part B: Engineering. 2012;43(4):1919-1928. DOI: 10.1016/j. compositesb.2012.02.027

8. Burciaga-Díaz O, Escalante-Garcia JI, Magallanes-Rivera RX Resistencia a la compresión y evolución microestructural de geopolímeros base metacaolín expuestos a alta temperatura Revista ALCONPAT. 2015;5(1):58-73.

9. Davidovits J. Geopolymers and geopolymeric materials. Journal of Thermal Analysis and Calorimetry. 1989;35(2):429-441.

10. Davidovits J. GP Camp 2014. State of the Geopolymer R\&D 2014 In: Geopolymer Camp 2014; 2014 Jul 7-9; University of Picardie, Saint-Quentin, France; 2014.

11. Paiva MDM, Silva ECCM, Melo DMA, Martinelli AE, Schneider JF. A geopolymer cementing system for oil wells subject to steam injection. Journal of Petroleum Science and Engineering. 2018;169:748-759. DOI: 10.1016/j.petrol.2018.06.022

12. He J, Zhang J, Yu Y, Zhang G. The strength and microstructure of two geopolymers derived from metakaolin and red mud-fly ash admixture: A comparative study. Construction and Building Materials. 2012;30:80-91

13. Meftah M, Oueslati W, Chorfi N, Ben Haj Amara A. Intrinsic parameters involved in the synthesis of metakaolin based geopolymer: Microstructure analysis. Journal of Alloys and Compounds. 2016;688(Pt B):946-956. DOI: 10.1016/j. jallcom.2016.07.297

14. Saikia NJ, Sengupta P, Gogoi PK, Borthakur PC. Cementitious properties of Metakaolin-normal Portland cement mixture in the presence of petroleum effluent treatment plant sludge. Cement and Concrete Research. 2002;32(11):1717-1724.

15. Mejía de Gutiérrez R, Torres AJ, Guerrero CE. Analysis of thermal process of pozzolan production. Materiales de Construcción. 2004;54(274):65-72. DOI: 10.3989/mc.2004. v54.i274.233

16. Caballero LR, Paiva MDM, Fairbairn EMR, Toledo Filho RD. Physical-Mechanical Behavior of Metakaolin Based Geopolymer Systems Reinforced with Stainless Steel Fibers. Materials Research Proceedings. 2018;7:295-312. 
17. American Petroleum Institute (API). API RP 10B-2 Recommended Practice for Testing Well Cements. Washington, DC: API; 2013.

18. Associação Brasileira de Normas Técnicas (ABNT). ABNT NBR 9831:2006 - Cimento Portland destinado à cimentação de poços petroliferos - Requisitos e métodos de ensaio. Versão Corrigida 24/11/2008. Rio de Janeiro: ABNT; 2006.

19. Associação Brasileira de Normas Técnicas (ABNT). ABNT NBR5739:2007 - Concreto - Ensaios de compressão e corposde-prova cilíndricos. Rio de Janeiro: ABNT; 2007.

20. Saikia N, Usami A, Kato S, Kojima T. Hydration Behaviour of Ecocement in Presence of Metakaolin. Resources Processing. 2004;51(1):35-41

21. Taha AS, El-Didamony H, Abo El Enein SA, Amer HA. Physicochemical properties of supersulphated cement pastes. Zement-Kalk-Gips. 1981;34(6):315-317.

22. Guo X, Shi H, Dick WA. Compressive strength and microstructural characteristics of class $\mathrm{C}$ fly ash geopolymer. Cement and Concrete Composites. 2010;32(2):142-147. DOI: doi.org/10.1016/j. cemconcomp.2009.11.003

23. Zhang S, Gong K, Lu J. Novel modification method for inorganic geopolymer by using water soluble organic polymers. Materials Letters. 2004;58(7-8):1292-1296. DOI: doi.org/10.1016/j. matlet.2003.07.051
24. Ferone C, Roviello G, Colangelo F, Cioffi R, Tarallo O. Novel hybrid organic-geopolymer materials. Applied Clay Science. 2013;73:42-50. DOI: doi.org/10.1016/j.clay.2012.11.001

25. Bernal SA, de Gutierrez RM, Provis JL, Rose V. Effect of silicate modulus and metakaolin incorporation on the carbonation of alkali silicate-activated slags. Cement and Concrete Research . 2010;40(6):898-907.

26. Reig L, Tashima MM, Borrachero MV, Monzó J, Cheeseman CR, Payá J. Properties and microstructure of alkali-activated red clay brick waste. Construction and Building Materials. 2013;43:98-106.

27. Duxson P. The structure and thermal evolution of metakaolin geopolymers. [Thesis]. Melbourne: University of Melbourne; 2006. 